\title{
Variable response of kochia [Kochia scoparia (L.) Schrad.] to auxinic herbicides dicamba and fluroxypyr in Montana
}

\author{
Prashant Jha, Vipan Kumar, and Charlemagne A. Lim \\ Montana State University-Bozeman, Southern Agricultural Research Center, Huntley, Montana \\ 59037, USA (e-mail: pjha@montana.edu). Received 14 January 2015, accepted 13 May 2015. \\ Published on the web 8 June 2015.
}

\begin{abstract}
Jha, P., Kumar, V. and Lim, C. A. 2015. Variable response of kochia [Kochia scoparia (L.) Schrad.] to auxinic herbicides dicamba and fluroxypyr in Montana. Can. J. Plant Sci. 95: 965-972. Herbicide-resistant kochia is an increasing concern for growers in the Northern Great Plains of United States and Canada. The objective of the research was to characterize the response of the three putative auxinic herbicide-resistant kochia inbreds (derived from accessions collected from wheat/ chemical fallow fields in northern Montana) to dicamba and fluroxypyr relative to a susceptible (SUS) inbred. A dicamba dose-response study indicated that the three putative resistant inbreds (Chot-01, Chot-02, and Chot-03) had R/S ratios of 1.3 to 6.1 based on the visible control response ( $\mathrm{I}_{50}$ values), and $\mathrm{R} / \mathrm{S}$ ratios of 1.5 to 6.8 based on the shoot dry weight response $\left(\mathrm{GR}_{50}\right.$ values). Dose-response experiments with fluroxypyr determined $\mathrm{I}_{50} \mathrm{R} / \mathrm{S}$ ratios of 1.4 to 5.7 and $\mathrm{GR}{ }_{50} \mathrm{R} / \mathrm{S}$ ratios of 1.6 to 4.0 for the three putative resistant inbreds. The selected inbreds showed variable symptomology (phenotype) in response to dicamba and fluroxypyr. Among the three inbreds, Chot-01 exhibited the least epinasty, stem curling/swelling, and chlorosis/necrosis symptoms, and was resistant to dicamba and fluroxypyr. Growers should diversify their weed management tools to manage further spread of auxinic or multiple herbicide-resistant kochia in the region.
\end{abstract}

Key words: Auxinic herbicide, dicamba, fluroxypyr, herbicide resistance, dose-response

\begin{abstract}
Jha, P., Kumar, V. et Lim, C. A. 2015. Variabilité de la réaction de la kochie [Kochia scoparia (L.) Schrad.] aux herbicides auxiniques dicamba et fluroxypyr au Montana. Can. J. Plant Sci. 95: 965-972. La résistance de la kochie aux herbicides est un souci croissant pour les cultivateurs du nord des grandes plaines, aux États-Unis et au Canada. L'étude devait comparer la réaction de trois lignées autogames de kochie qu'on soupçonne résister aux herbicides auxiniques (issues d'obtentions glanées dans les champs de blé et les jachères chimiques du nord du Montana) au dicamba et au fluroxypyr à la réaction d'une lignée autogame sensible. L'étude dose-réponse sur le dicamba indique que les trois lignées autogames supposément résistantes (Chot-01, Chot-02 et Chot-03) présentent un rapport $\mathrm{R} / \mathrm{S}$ de 1,3 à 6,1 selon la destruction visible (valeur $\mathrm{I}_{50}$ ), et un rapport $\mathrm{R} / \mathrm{S}$ de 1,5 à 6,8 , d'après le poids sec des pousses (valeur $\mathrm{GR}_{50}$ ). Les expériences dose-réponse avec le fluroxypyr sur les trois lignées autogames prétendument résistantes ont pour leur part donné un rapport R/S de 1,4 à 5,7 pour les valeurs $\mathrm{I}_{50}$ et un rapport $\mathrm{R} / \mathrm{S}$ de 1,6 à 4,0 pour les valeurs $\mathrm{GR}_{50}$. Les lignées autogames choisies présentaient des symptômes variables (phénotype) à la suite du traitement au dicamba et au fluroxypyr. Parmi les trois, Chot-01 était celle qui présentait le moins d'épinastie, de gonflement et d'enroulement des tiges et de chlorose ou de nécrose, et résistait aux deux herbicides. Les cultivateurs devraient diversifier leurs moyens de gestion des mauvaises herbes pour empêcher une plus grande prolifération des variétés de kochie qui résistent aux herbicides auxiniques ou à plusieurs herbicides dans la région.
\end{abstract}

Mots clés: Herbicide auxinique, dicamba, fluroxypyr, résistance aux herbicides, dose-réponse

Kochia, a $\mathrm{C}_{4}$ summer annual, is one of the most troublesome dicot weeds in cropland and non-cropland areas across the Northern Great Plains of the United States and Canada (Eberlein and Fore 1984; Wicks et al. 1994). The invasiveness of kochia is attributed to its unique biological characteristics, including early seedling emergence, $\mathrm{C}_{4}$ photosynthesis, rapid growth, heat and salt tolerance, and prolific seed production ( $>50000$ seeds plant $^{-1}$ ) (Christoffoleti et al. 1997; Schwinghamer and Van Acker 2008; Friesen et al. 2009). At maturity, the plant breaks off at the base of the stem and tumbles with the prevailing wind, ensuring long-distance seed dispersal (Baker et al. 2010). Kochia is a facultative open pollinator, and the protogynous flowering enforces out-crossing and pollen-mediated gene flow; consequently, there is a high genetic variation within and among kochia populations
(Stallings et al. 1995; Mengistu and Messersmith 2002). These characteristics allow rapid evolution and spread of resistant alleles in kochia populations under herbicide selection.

Growers in the Northern Great Plains region of the United States and Canada are facing ever-increasing challenges in controlling kochia in their production fields because of the occurrence of populations resistant to one or more herbicide families (Heap 2014). Kochia populations resistant to photosystem II (PS II) and acetolactate synthase (ALS) inhibitors are widely spread across Montana and several other states in this region (Primiani et al. 1990; Beckie et al. 2011; Heap 2014).

Abbreviations: ALS, acetolactate synthase; DAA, days after application; SUS, susceptible 
More recently, glyphosate-resistant kochia has been confirmed in nine states of the US Great Plains, including Montana, and in southern Alberta, Saskatchewan, and Manitoba, Canada (Beckie et al. 2013; Hall et al. 2014; Heap 2014; Kumar et al. 2014a). Auxinic herbicides such as dicamba (labeled in wheat, corn, and chemical fallow) and fluroxypyr (labeled in wheat and corn) are effective for controlling glyphosate- and ALSinhibitor-resistant kochia (Burton et al. 2014; Kumar et al. 2014a); however, occurrence of auxinic herbicideresistant kochia in wheat and corn fields in the region (Heap 2014) is a potential concern.

Auxinic herbicides are often used to control weed populations resistant to other herbicides. This may be because of a relatively few cases of resistance development in weed species to these herbicides besides their use for almost six decades (Preston et al. 2009; Mithila et al. 2011; Heap 2014). The field-use rate of dicamba in wheat is 70 to $140 \mathrm{~g} \mathrm{ha}^{-1}$, and in corn is 280 to $560 \mathrm{~g} \mathrm{ha}^{-1}$ (Anonymous 2014a). In the mid to late 1990s, researchers observed a lack of kochia control with dicamba use rates of 70 to $280 \mathrm{~g} \mathrm{ha}^{-1}$ in wheat or corn (Miller et al. 1997; Howatt 1999). Dicamba-resistant kochia was first reported in 1994 in wheat fields near Fort Benton, Montana, USA (Cranston et al. 2001; Dyer et al. 2001; Goss and Dyer 2003). Subsequently, it was reported in corn and/or wheat in North Dakota, Colorado, and Nebraska, USA (Nandula and Manthey, 2002; Howatt et al. 2006; Crespo et al. 2014).

Cranston et al. (2001) reported that an inbred resistant line derived from a field-collected accession of kochia in Montana was 4.6-fold more resistant to dicamba than a susceptible inbred line. Nandula and Manthey (2002) reported resistance index of 5- to 10 -fold in dicambaresistant kochia inbreds from North Dakota. A 30-fold level of resistance to dicamba was reported in an inbred developed from a field population of kochia near Scotts Bluff County, Nebraska (Preston et al. 2009). In a recent survey conducted in Nebraska, a kochia accession had 17- to 19-fold levels of resistance to dicamba; the accession was collected from fields where dicamba was used for weed control in corn or wheat stubble over $10 \mathrm{yr}$ (Crespo et al. 2014). It is evident that the resistance alleles can accumulate over several generations of recurrent selection, thereby conferring a high level of resistance to the herbicide (Preston et al. 2009).

In response to grower complains on kochia control failures with dicamba in wheat/chemical fallow fields in 2011, we collected and investigated three kochia accessions from Choteau County, Montana, for differential response to dicamba. To investigate possible development of cross-resistance to fluroxypyr, another commonly used and effective auxinic herbicide for kochia control in wheat, we also tested the response of those three selected accessions to fluroxypyr. The field-use rate of fluroxypyr in wheat is $157 \mathrm{~g}$ a.e. ha ${ }^{-1}$ (Anonymous 2014b). The objective of this research was to confirm and characterize the response of selected kochia inbreds (derived from field-collected accessions) from Montana to dicamba and fluroxypyr herbicides.

\section{MATERIALS AND METHODS}

\section{Seed Source}

Three putative auxinic herbicide-resistant kochia accessions were collected in fall 2011 from three different wheat fields in Choteau County, Montana, USA. The three sites were within $5 \mathrm{~km}$ from each other, and the accessions were referred to as Chot-01, Chot-02, and Chot-03, respectively. The sampled grower fields were under dryland no-till wheat-fallow rotation for $>8 \mathrm{yr}$, with a history of repeated use of dicamba, fluroxypyr, or both in wheat in conjunction with sulfonylurea herbicides. Also, dicamba was used in conjunction with 2,4-D or glyphosate for weed control in the chemical fallow. At each of the three sites, kochia seeds were collected from 5 to 10 arbitrarily selected large and mature plants that survived in-season applications of dicamba or fluroxypyr at the recommended field-use rates and weed size. Seeds from the selected plants in a field were combined into a composite sample. The susceptible accession (designated SUS) was collected from a wheat field in Huntley, Montana, used for long-term organic trials, and was known to be susceptible to the herbicides tested.

\section{Development of Kochia Inbreds}

Field-collected seeds of putative resistant (Chot-01, Chot-02, and Chot-03) and SUS kochia accessions were sown separately on the surface of 53 by 35 by $10 \mathrm{~cm}$ flats filled with a commercial potting media (VermiSoil, Vermicrop Organics, 4265 Duluth Ave, Rocklin, CA) in a greenhouse at the Montana State University-Southern Agricultural Research Center, near Huntley, Montana in spring 2012. The greenhouse was maintained at 26/23 \pm $3^{\circ} \mathrm{C}$ day/night temperatures and $16 / 8 \mathrm{~h}$ day/night photoperiods, and the supplemental light $\left(400 \mu \mathrm{mol} \mathrm{m}^{-2} \mathrm{~s}^{-1}\right)$ was provided by metal halide lamps. The emerged seedlings of each accession were further transplanted into three separate trays (50 seedlings per tray). Actively growing 8- to $10-\mathrm{cm}$-tall kochia plants in a tray were sprayed with a discriminating dose (field use-rate in wheat or corn) of either dicamba (Banvel, BASF Corporation, Research Triangle Park, NC) at 280 g a.e. ha ${ }^{-1}$, fluroxypyr (Starane Ultra, Dow AgroSciences LLC., 9330 Zionsville Road, Indianapolis, IN) at $157 \mathrm{~g}$ a.e. $\mathrm{ha}^{-1}$, or both. Applications were made inside a stationary cabinet spray chamber (Research Track Sprayer, De Vries Manufacturing, RR 1 Box 184, Hollandale, MN) equipped with a flat-fan nozzle tip (TeeJet 8001XR, Spraying System Co., Wheaton, IL), calibrated to deliver $94 \mathrm{~L} \mathrm{ha}^{-1}$ of spray solution at $276 \mathrm{kPa}$. After the herbicide application, plants were returned to the greenhouse, watered daily to avoid moisture stress, and fertilized [Miracle-Gro water soluble fertilizer (24-816), Scotts Miracle-Gro Products Inc., 14111 Scottslawn 
Road, Marysville, $\mathrm{OH}$ ] weekly to maintain good growth. Visible percent control were assessed on a scale of 0 to 100 $(0=$ no control and $100=$ complete control $/$ plant death $)$ at 7, 14, and $28 \mathrm{~d}$ after application (DAA).

For each putative resistant kochia accession, 20 phenotypically uniform plants that survived the discriminating doses of dicamba and fluroxypyr both, with little $(<25 \%)$ to no injury symptoms were selected. Those survivors were grown in the greenhouse in $3.5-\mathrm{L}$ plastic pots. Individual plants were covered with pollen bags to avoid cross-pollination. Upon maturity, seeds were collected from the individual plants, and bulked for each accession. Inbred lines were developed (spring 2012 to fall 2013) after three generations of group (to avoid inbreeding depression) recurrent selection (two generations with dicamba or fluroxypyr and one generation without an herbicide) to obtain relatively homozygous phenotypes for dicamba or fluroxypyr resistance. Inbred lines selected with dicamba or fluroxypyr were used for the dicamba or fluroxypyr dose-response experiments, respectively. The inbred line for the SUS accession (susceptible to both dicamba and fluroxypyr) was developed by selfing a group of plants under pollen isolation conditions for three generations in the greenhouse.

\section{Whole-Plant Dose-Response of Kochia Inbreds}

Two separate whole-plant dose-response experiments were conducted in the spring of 2014 in the greenhouse to determine the variable response of inbred kochia accessions (Chot-01, Chot-02, and Chot-03) to dicamba and fluroxypyr. Seeds of each accession were sown separately on the flats, and single seedlings were transplanted into $10-\mathrm{cm}$-diam pots in the greenhouse under similar conditions described previously. The experiment was a randomized complete block design with eight replications (one plant per pot) for each treatment and was repeated in time.

Actively growing 8- to $10-\mathrm{cm}$-tall kochia plants from each accession were sprayed with dicamba at doses of 0 , $2,4,9,18,36,70,140,280,420,560,840,1100,2200$, and $3400 \mathrm{~g}$ a.e. ha ${ }^{-1}$. Fluroxypyr was applied at doses of $0,17.5,35,70,140,210,280,420,560,840$, and $1100 \mathrm{~g}$ a.e. $\mathrm{ha}^{-1}$. Applications were made inside a stationary cabinet spray chamber. Plants were returned to the greenhouse, watered daily to avoid moisture stress, and fertilized weekly to maintain good growth described previously. Visible percent control was determined at 7, 14, and 28 DAA. Plants were harvested at the soil level at 28 DAA, and dried at $60^{\circ} \mathrm{C}$ for $3 \mathrm{~d}$ to determine shoot dry weight, calculated as a percentage of the nontreated control.

\section{Statistical Analyses}

Data from whole-plant dose-response experiments for dicamba and fluroxypyr were analyzed separately. Data were subjected to ANOVA using PROC MIXED in SAS (SAS ${ }^{\circledR}$, SAS Institute Inc., Cary, NC) to test the significance of experiment run, replication, accession (inbred), herbicide dose, and their interactions. Residual analyses were performed on visually assessed percent control and shoot dry weight (\% of nontreated) using PROC UNIVARIATE in SAS, which revealed that the distribution of residuals met the criteria for ANOVA. For both dicamba and fluroxypyr dose-response experiments, data were pooled across experiment runs on the basis of nonsignificant interaction of experiment run by treatment, and tested for homogeneity of variance. Arcsine-transformation of percent control and shoot dry weight (percent of nontreated) data did not improve the results; therefore, nontransformed data were used for further analysis. Data for each kochia inbred were regressed over herbicide doses using the four-parameter log-logistic model (Seefeldt et al. 1995):

$$
Y=C+\{D-C / 1+\exp [B(\log X-\log E)]\}
$$

where $Y$ is the response variable (percent control or shoot dry weight as a percentage of nontreated), $C$ is the lower limit, $D$ is the upper limit, $B$ is the slope of each curve, $E$ is the dicamba or fluroxypyr dose required for $50 \%$ response (e.g., $50 \%$ control referred as $\mathrm{I}_{50}$ or $50 \%$ reduction in shoot dry weight referred as $\mathrm{GR}_{50}$ ), and $X$ is the herbicide dose. The lack-of-fit $\mathrm{F}$ test $(P<0.05)$ indicated that the nonlinear model accurately described the data. Analysis of the dose-response curves, parameter estimates, standard errors, and $\mathrm{I}_{90}$ or $\mathrm{GR}_{90}$ values (herbicide dose required for $90 \%$ control or $90 \%$ reduction in shoot dry weight) were determined utilizing $d r c$ package in $R$ software (Knezevic et al. 2007). Based on $\mathrm{I}_{50}$ or $\mathrm{GR}_{50}$ values, the level of resistance (referred to as $\mathrm{R} / \mathrm{S}$ ratio) for each kochia inbred was calculated by dividing the $\mathrm{I}_{50}$ or $\mathrm{GR}_{50}$ value of the putative resistant inbred by the $I_{50}$ or $G_{5 R}$ value of the SUS inbred. An approximate $t$-test was performed to determine whether the relative differences (estimated ratios) of the $I_{50}$, $\mathrm{GR}_{50}, \mathrm{I}_{90}$, or $\mathrm{GR}_{90}$ values among the inbreds were significant at $\alpha=0.05$ (Knezevic et al. 2007).

\section{RESULTS AND DISCUSSION}

\section{Dicamba Dose-Response of Kochia Inbreds}

On the basis of visible percent control 28 DAA, $\mathrm{I}_{50}$ values for the putative auxinic herbicide-resistant Chot-01, Chot-02, and Chot-03 inbreds were 746, 314, and $158 \mathrm{~g}$ $\mathrm{ha}^{-1}$, respectively, and were higher than the $\mathrm{I}_{50}$ value of the SUS inbred (Table 1; Fig. 1). The $\mathrm{I}_{90}$ values for the Chot-01, Chot-02, and Chot-03 inbreds were 2074, 2445, and $1120 \mathrm{~g} \mathrm{ha}^{-1}$, respectively, indicating that 1.9 to 4.2 times more dose of dicamba would be needed to obtain $90 \%$ control of those inbreds compared with the SUS inbred. The three putative resistant kochia inbreds exhibited $\mathrm{I}_{50} \mathrm{R} / \mathrm{S}$ ratios of 1.3 to 6.1 .

On the basis of shoot dry weight dose-response 28 DAA, GR $_{50}$ values for the Chot-01, Chot-02, and Chot-03 inbreds were 844,306 , and $180 \mathrm{~g} \mathrm{ha}^{-1}$, respectively, and were higher compared with the SUS inbred (Table 1; Fig. 2). The $\mathrm{GR}_{90}$ values for the putative resistant inbreds were 3 to 10 times greater than the SUS inbred, and 
Table 1. Regression parameters for whole-plant dose-response on the basis of visible control and shoot dry weight (percentage of nontreated) of kochia inbreds treated with dicamba

\begin{tabular}{|c|c|c|c|c|c|c|}
\hline \multicolumn{7}{|c|}{ Regression parameters } \\
\hline Inbred $^{\mathbf{z}}$ & $d( \pm \mathrm{SE})$ & $c( \pm \mathrm{SE})$ & $b( \pm \mathrm{SE})$ & $\mathrm{I}_{50}$ or $\mathrm{GR}_{50}(95 \% \mathrm{CI})$ & $\mathrm{I}_{90}$ or $\mathrm{GR}_{90}(95 \% \mathrm{CI})$ & $\mathrm{R} / \mathrm{S}^{\mathrm{y}}$ \\
\hline \multicolumn{7}{|c|}{ Visual control } \\
\hline Chot-01 & $87.2(2.7)$ & $3.6(0.8)$ & $-2.1(0.2)$ & $746(674-817)$ & $2074(1540-2610)$ & 6.1 \\
\hline Chot-02 & $93.9(3.2)$ & $0.2(1.1)$ & $-1.1(0.1)$ & $314(260-368)$ & $2445(1377-3513)$ & 2.6 \\
\hline Chot-03 & $95.4(2.2)$ & $2.1(1.2)$ & $-1.1(0.1)$ & $158(138-180)$ & $1120(726-1514)$ & 1.3 \\
\hline \multicolumn{7}{|c|}{ Shoot dry weight } \\
\hline SUS & $93.5(1.2)$ & $-3.2(1.7)$ & $1.1(0.1)$ & $124(110-138)$ & $897(642-1152)$ & - \\
\hline Chot-01 & $97.5(0.8)$ & $-2.9(8.6)$ & $1.0(0.1)$ & $844(507-1181)$ & $8975(6209-11286)$ & 6.8 \\
\hline Chot-02 & $98.3(1.4)$ & $-0.1(4.1)$ & $0.8(0.1)$ & $306(227-385)$ & $5386(3782-8990)$ & 2.5 \\
\hline Chot-03 & $97.3(1.4)$ & 0.1 (3.1) & $0.8(0.1)$ & $180(145-216)$ & $2766(1334-4198)$ & 1.5 \\
\hline
\end{tabular}

${ }^{\mathbf{z}}$ Abbreviations: SUS, susceptible inbred, Montana; Chot-01, putative resistant inbred \#1, Montana; Chot-02, putative resistant inbred \#2, Montana; Chot-03, putative resistant inbred \#3, Montana; $\mathrm{SE}$, standard error; $95 \% \mathrm{CI}$, approximate $95 \%$ confidence interval; $\mathrm{I}_{50}$ and $\mathrm{GR}_{50}$ are effective doses (g a.e. ha ${ }^{-1}$ ) of dicamba required for $50 \%$ visible control and shoot dry weight reduction, respectively; $\mathrm{I}_{90}$ and $\mathrm{GR}_{90}$ are effective doses $\left(\mathrm{g}\right.$ a.e. ha ${ }^{-1}$ ) of dicamba required for $90 \%$ visible control and shoot dry weight reduction, respectively.

${ }^{y} \mathrm{R} / \mathrm{S}$ is calculated as a ratio of $\mathrm{I}_{50}$ or $\mathrm{GR}_{50}$ of a putative resistant inbred to $\mathrm{I}_{50}$ or $\mathrm{GR}_{50}$ of the SUS inbred.

10 to 32 times the dicamba field-use rate of $280 \mathrm{~g} \mathrm{ha}^{-1}$ labeled for maize, and 20 to 64 times the use rate of $140 \mathrm{~g} \mathrm{ha}^{-1}$ labeled for wheat. The $\mathrm{GR}_{50} \mathrm{R} / \mathrm{S}$ ratios indicated that the three selected kochia inbreds were 1.5- to 6.8-folds less susceptible to dicamba than the SUS inbred.

The relative differences of $\mathrm{I}_{50}$ or $\mathrm{GR}_{50}$ values (estimated ratios) among curves suggested a variable phenotypic response of the three putative resistant inbreds to dicamba (Table 2). Visibly, the Chot-01 inbred had relatively less epinasty and stem curling/swelling symptoms, and remained relatively greener compared with

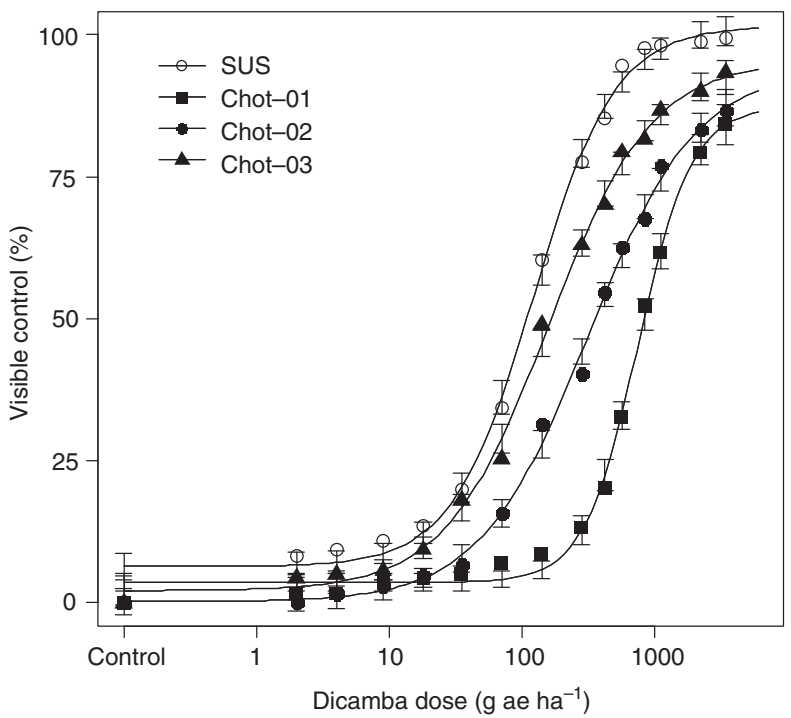

Fig. 1. Visible control response of three putative auxinic herbicide-resistant kochia inbreds (Chot-01, Chot-02, and Chot-03 from Choteau County, Montana) and a susceptible inbred (SUS from Huntley, Montana) treated with dicamba in a whole-plant dose-response experiment. Vertical bars represent the model-based estimated standard error of the mean. the Chot-02 and Chot-03 accessions at 28 DAA. Overall, the hierarchy of resistance to dicamba on the basis of $\mathrm{I}_{50}$ or $\mathrm{GR}_{50}$ values was: Chot-01 $>$ Chot- $02>$ Chot- 03 (Table 2). Although not biologically meaningful, no significant differences were observed in the $\mathrm{GR}_{90}$ values among the three putative resistant inbreds (Table 2). In North Dakota, Nandula and Manthey (2002) reported kochia accessions with 5- to 10 -fold levels of resistance to dicamba. Among the seven field accessions of kochia from Nebraska, there was a less than 2.5-fold variation in response to dicamba between the least-susceptible and

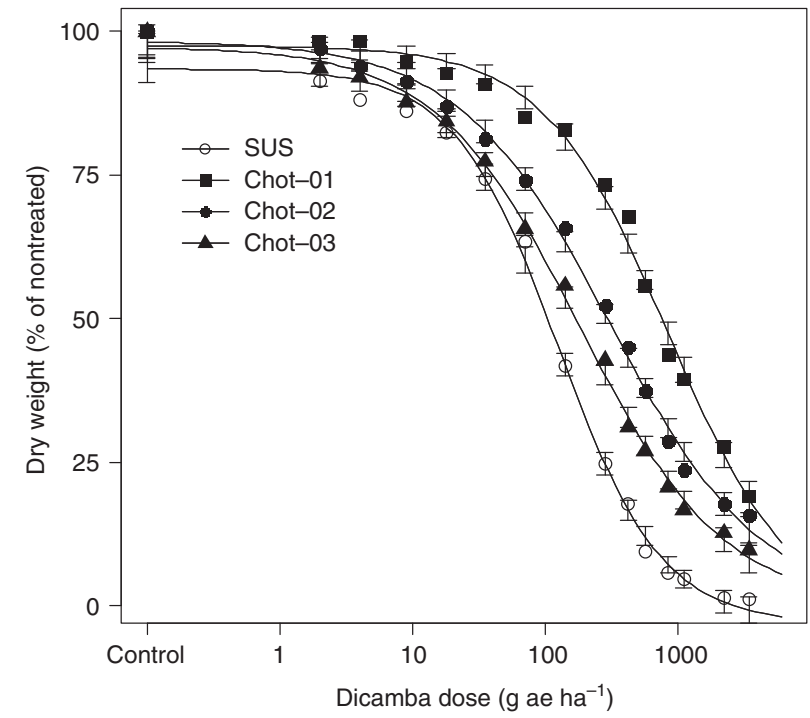

Fig. 2. Shoot dry weight response of three putative auxinic herbicide-resistant kochia inbreds (Chot-01, Chot-02, and Chot-03 from Choteau County, Montana) and a susceptible inbred (SUS from Huntley, Montana) treated with dicamba in a whole-plant dose-response experiment. Vertical bars represent the model-based estimated standard error of the mean. 
Table 2. Approximate $\boldsymbol{t}$-test for comparison of relative differences of $\mathbf{I}_{\mathbf{5 0}}$, $I_{90}, G R_{50}$, or $G R_{90}$ values among kochia inbreds treated with dicamba in whole-plant dose-response experiments

\begin{tabular}{lcrrr}
\hline & \multicolumn{4}{c}{ Estimated ratio $^{\mathbf{z}}$} \\
\cline { 2 - 5 } Inbred $^{\mathbf{y}}$ & $\mathrm{I}_{50}$ & \multicolumn{1}{c}{$P>F$} & $\mathrm{GR}_{50}$ & $P>F$ \\
\hline Chot-01:SUS & 6.1147 & $<0.0001$ & 6.8064 & $<0.0001$ \\
Chot-02:SUS & 2.5737 & $<0.0001$ & 2.4677 & $<0.0001$ \\
Chot-03:SUS & 1.2950 & 0.0014 & 1.4516 & $<0.0001$ \\
Chot-01:Chot-02 & 2.3741 & $<0.0001$ & 2.7581 & 0.0089 \\
Chot-01:Chot-03 & 4.7215 & $<0.0001$ & 4.6888 & 0.0006 \\
Chot-02:Chot-03 & 1.9873 & $<0.0001$ & 1.7000 & 0.0135 \\
& $\mathrm{I} 90$ & & GR & \\
Chot-01:SUS & 3.6006 & $<0.0001$ & 10.0055 & $<0.0001$ \\
Chot-02:SUS & 4.2447 & $<0.0001$ & 6.0044 & $<0.0001$ \\
Chot-03:SUS & 1.9444 & $<0.0001$ & 3.0836 & $<0.0001$ \\
Chot-01:Chot-02 & 0.8482 & 0.4890 & 1.6663 & 0.4905 \\
Chot-01:Chot-03 & 1.8517 & 0.0387 & 3.2447 & 0.1997 \\
Chot-02:Chot-03 & 2.1830 & 0.0582 & 1.9472 & 0.2578 \\
\hline
\end{tabular}

${ }^{\mathbf{z}}$ Approximate $t$-test on estimated ratios of $\mathrm{I}_{50}, \mathrm{GR}_{50}, \mathrm{I}_{90}$, or $\mathrm{GR}_{90}$ values among kochia inbreds was performed with the selectivity indices (SI) command in ' $R$ ' software (Knezevic et al. 2007).

${ }^{\mathbf{y}}$ Abbreviations: SUS, susceptible inbred, Montana; Chot-01, putative resistant inbred \#1, Montana; Chot-02, putative resistant inbred \#2, Montana; Chot-03, putative resistant inbred \#3, Montana; $\mathrm{I}_{50}$ and $\mathrm{GR}_{50}$ are effective doses (g a.e. $\mathrm{ha}^{-1}$ ) of dicamba required for $50 \%$ visible control and shoot dry weight reduction, respectively. $I_{90}$ and $\mathrm{GR}_{90}$ are effective doses (g a.e. ha ${ }^{-1}$ ) of dicamba required for $90 \%$ visible control and shoot dry weight reduction, respectively.

most-susceptible accession; $\mathrm{I}_{50}$ value ranged from 270 to $450 \mathrm{~g} \mathrm{ha}^{-1}$ and $\mathrm{GR}_{50}$ value ranged from 310 to $670 \mathrm{~g} \mathrm{ha}^{-1}$ (Crespo et al. 2014). In the same study, one accession exhibited relatively high $\mathrm{I}_{50}$ and $\mathrm{GR}_{50}$ values of 5120 $\mathrm{g} \mathrm{ha}^{-1}$ and $3490 \mathrm{~g} \mathrm{ha}^{-1}$, respectively, and large $\mathrm{R} / \mathrm{S}$ ratios of 17.0 to 19.0 (Crespo et al. 2014). Unlike our study with inbred lines derived from field-collected plants, the dose-response study by Crespo et al. (2014) was conducted using field-collected seeds and in the absence of a homogenous susceptible line, which may cause an inaccurate prediction of resistance level $(\mathrm{R} / \mathrm{S}$ ratio). Compared with $\mathrm{R} / \mathrm{S}$ ratios up to 6.8 observed in our study, Cranston et al. (2001) reported up to 4.5 -fold levels of dicamba resistance in kochia accessions collected in 1993/1994 from Montana, which further suggests that susceptibility to dicamba is decreasing at a slow, but steady rate in kochia populations.

\section{Fluroxypyr Dose-Response of Kochia Inbreds}

On the basis of visible percent control, $\mathrm{I}_{50}$ values for the Chot-01, Chot-02, and Chot-03 kochia accessions were 176, 55, and $44 \mathrm{~g} \mathrm{ha}^{-1}$, respectively, compared with $31 \mathrm{~g} \mathrm{ha}^{-1}$ for the SUS inbred (Table 3; Fig. 3). The I ${ }_{90}$ values for the Chot-01, Chot-02, and Chot-03 inbreds were 869,407 , and $369 \mathrm{~g} \mathrm{ha}^{-1}$, respectively, compared with $159 \mathrm{~g} \mathrm{ha}^{-1}$ for the SUS inbred, indicating that 2.3 to 5.5 times more dose of fluroxypyr would be needed to obtain $90 \%$ control of the putative resistant inbreds relative to the SUS inbred. Based on the $\mathrm{I}_{50} \mathrm{R} / \mathrm{S}$ ratios, the three putative resistant inbreds had $\mathrm{R} / \mathrm{S}$ ratios of 1.4 to 5.7 .

On the basis of shoot dry weight response, $\mathrm{GR}_{50}$ values for the Chot-01, Chot-02, and Chot-03 inbreds were 124,63 , and $49 \mathrm{~g} \mathrm{ha}^{-1}$, respectively, compared with $31 \mathrm{~g} \mathrm{ha}^{-1}$ for the SUS inbred (Table 3; Fig. 4). The $\mathrm{GR}_{50} \mathrm{R} / \mathrm{S}$ ratios of the putative resistant inbreds were 1.6 to 4.0. Fluroxypyr doses of 1419,807 , and 819 $\mathrm{g} \mathrm{ha}^{-1}$ were needed to achieve $90 \%$ growth reduction of Chot-01, Chot-02, and Chot-03 inbreds, respectively, compared with the SUS plants $\left(\mathrm{GR}_{90}\right.$ of $\left.236 \mathrm{~g} \mathrm{ha}^{-1}\right)$. These results further suggest that five to nine times the field-use rate of fluroxypyr $\left(157 \mathrm{~g} \mathrm{ha}^{-1}\right)$ would be needed to achieve $90 \%$ growth reduction of the three putative resistant inbreds tested.

Additionally, the three putative auxinic herbicideresistant kochia inbreds showed variable phenotypic

Table 3. Regression parameters for whole-plant dose-response on the basis of visible control and shoot dry weight (\% of nontreated) of kochia inbreds treated with fluroxypyr

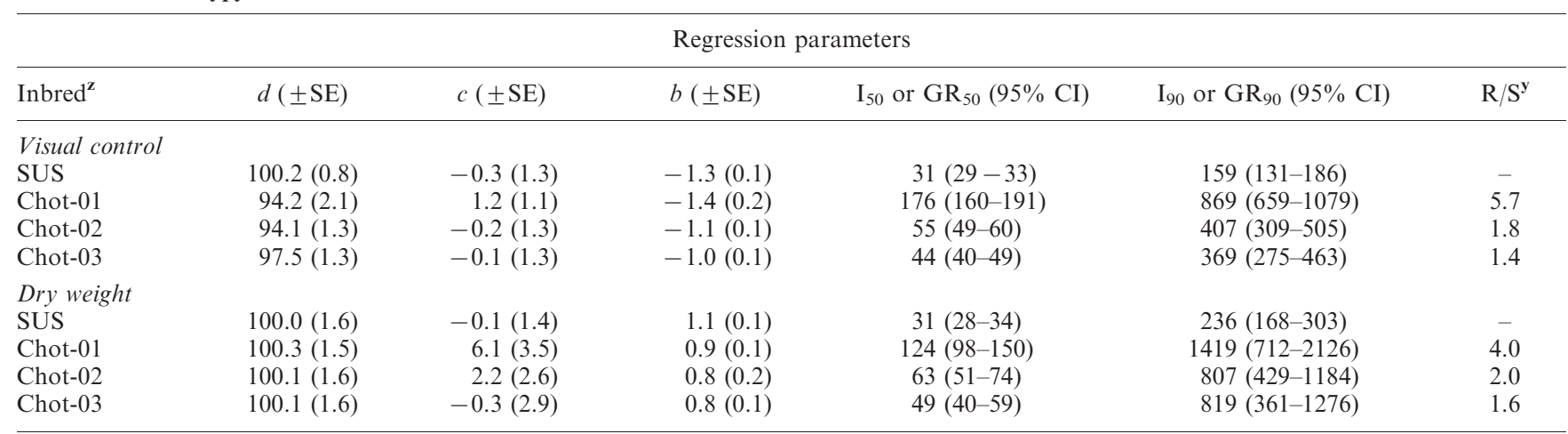

${ }^{\mathbf{z}}$ Abbreviations: SUS, susceptible inbred, Montana; Chot-01, putative resistant inbred \#1, Montana; Chot-02, putative resistant inbred \#2, Montana; Chot-03, putative resistant inbred \#3, Montana; SE, standard error; $95 \%$ CI, approximate $95 \%$ confidence interval; $I_{50}$ and GR $_{50}$ are effective doses (g a.e. $\mathrm{ha}^{-1}$ ) of fluroxypyr required for $50 \%$ visible control and shoot dry weight reduction, respectively; $\mathrm{I}_{90}$ and $\mathrm{GR}_{90}$ are effective doses (g a.e. $\mathrm{ha}^{-1}$ ) of fluroxypyr required for $90 \%$ visible control and shoot dry weight reduction, respectively.

${ }^{\mathbf{y}_{\mathrm{R}}} \mathrm{R} / \mathrm{S}$ is calculated as a ratio of $\mathrm{I}_{50}$ or $\mathrm{GR}_{50}$ of a putative resistant inbred to $\mathrm{I}_{50}$ or $\mathrm{GR}_{50}$ of the SUS inbred. 


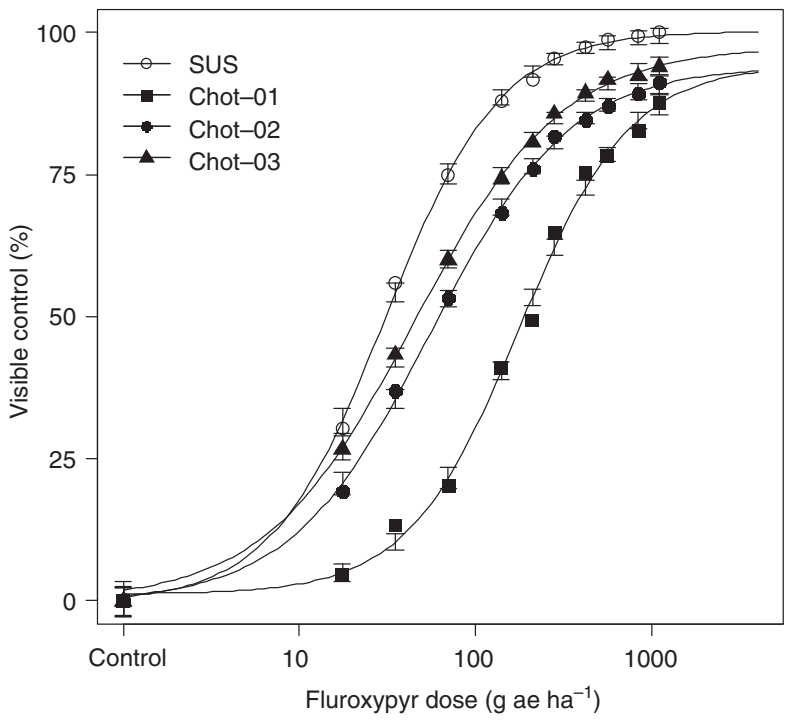

Fig. 3. Visible control response of three putative auxinic herbicide-resistant kochia inbreds (Chot-01, Chot-02, and Chot-03 from Choteau County, Montana) and a susceptible inbred (SUS from Huntley, Montana) treated with fluroxypyr in a whole-plant dose-response experiment. Vertical bars represent the model-based estimated standard error of the mean.

response to fluroxypyr (Table 4). On the basis of relative differences in $\mathrm{I}_{50}$ or $\mathrm{GR}_{50}$ values (estimated ratios) among inbreds, the hierarchy of resistance to fluroxypyr was: Chot-01 $>$ Chot-02 $\geq$ Chot-03. Compared with the Chot-02 and Chot-03 inbreds, Chot-01 inbred showed relatively mild epinasty, chlorosis/necrosis, and remained more

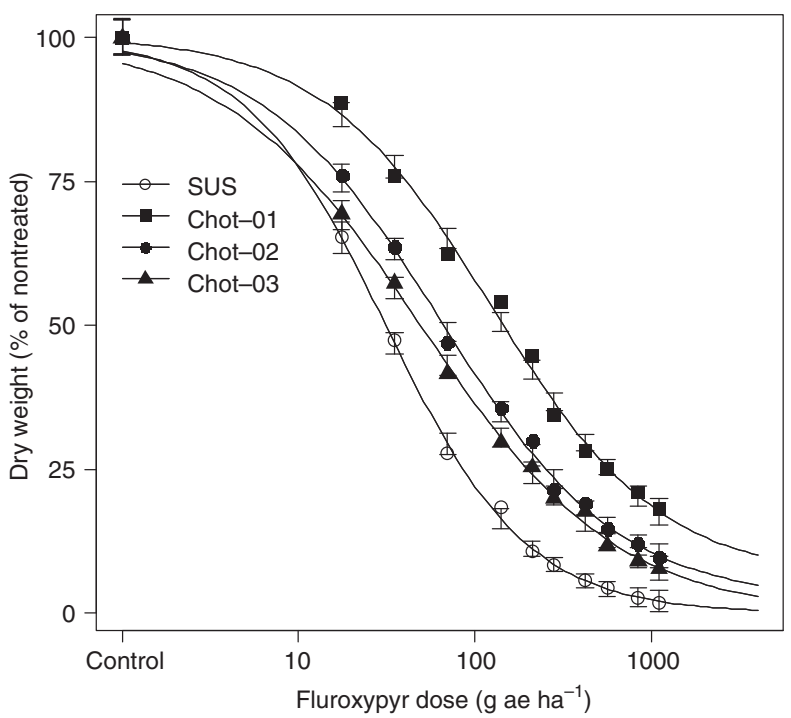

Fig. 4. Shoot dry weight response of three putative auxinic herbicide-resistant kochia inbreds (Chot-01, Chot-02, and Chot-03 from Choteau County, Montana) and a susceptible inbred (SUS from Huntley, Montana) treated with fluroxypyr in a whole-plant dose-response experiment. Vertical bars represent the model-based estimated standard error of the mean.
Table 4. Approximate $\boldsymbol{t}$-test for comparison of relative differences of $I_{50}$, $I_{90}, G R_{50}$, and $G R_{90}$ values of kochia inbreds treated with fluroxypyr in whole-plant dose-response experiments

\begin{tabular}{lcccr}
\hline & \multicolumn{4}{c}{ Estimated ratio $^{\mathbf{z}}$} \\
\cline { 2 - 5 } Inbred $^{\mathbf{y}}$ & $\mathrm{I}_{50}$ & $P>F$ & $\mathrm{GR}_{50}$ & $P>F$ \\
\hline Chot-01:SUS & 5.6774 & $<0.0001$ & 4.0000 & $<0.0001$ \\
Chot-02:SUS & 1.7741 & $<0.0001$ & 2.0322 & $<0.0001$ \\
Chot-03:SUS & 1.4193 & $<0.0001$ & 1.5806 & $<0.0001$ \\
Chot-01:Chot-02 & 3.2000 & $<0.0001$ & 1.9682 & 0.0005 \\
Chot-01:Chot-03 & 4.0000 & $<0.0001$ & 2.5306 & 0.0001 \\
Chot-02:Chot-03 & 1.2500 & 0.0082 & 1.2857 & 0.1120 \\
& $\mathrm{I}_{90}$ & & $\mathrm{GR}_{90}$ & \\
Chot-01:SUS & 5.4654 & $<0.0001$ & 6.0127 & $<0.0001$ \\
Chot-02:SUS & 2.5597 & $<0.0001$ & 3.4194 & $<0.0001$ \\
Chot-03:SUS & 2.3207 & $<0.0001$ & 3.4703 & $<0.0001$ \\
Chot-01:Chot-02 & 2.1351 & 0.0026 & 1.7583 & 0.2138 \\
Chot-01:Chot-03 & 2.3550 & 0.0016 & 1.7326 & 0.2654 \\
Chot-02:Chot-03 & 1.1029 & 0.6039 & 0.9853 & 0.9682 \\
\hline
\end{tabular}

${ }^{\mathrm{z}}$ Approximate $t$-test on estimated ratios of $\mathrm{I}_{50}, \mathrm{GR}_{50}, \mathrm{I}_{90}, \mathrm{GR}_{90}$ values among kochia inbreds was performed with the selectivity indices (SI) command in ' $R$ ' software (Knezevic et al. 2007).

${ }^{\mathbf{y}}$ Abbreviations: SUS, susceptible inbred, Montana; Chot-01, putative resistant inbred \#1, Montana; Chot-02, putative resistant inbred \#2, Montana; Chot-03, putative resistant inbred \#3, Montana; $\mathrm{I}_{50}$ and $\mathrm{GR}_{50}$ are effective doses $\left(\mathrm{g}\right.$ a.e. $\mathrm{ha}^{-1}$ ) of fluroxypyr required for $50 \%$ visible control and shoot dry weight reduction, respectively. $I_{90}$ and $\mathrm{GR}_{90}$ are effective doses $\left(\mathrm{g}\right.$ a.e. $\mathrm{ha}^{-1}$ ) of fluroxypyr required for $90 \%$ visible control and shoot dry weight reduction, respectively.

upright and green at 28 DAA. However, no relative differences among the putative resistant inbreds were evident on the basis of estimated $\mathrm{GR}_{90}$ values. Recently, kochia accessions with resistance to fluroxypyr have also been reported in North Dakota (Howatt and Ciernia 2014). In a dose-response study conducted by those researchers, the five accessions tested had up to sixfold levels of resistance to fluroxypyr relative to a susceptible accession, and fluroxypyr doses $\geq 1120 \mathrm{~g} \mathrm{ha}^{-1}$ were needed to achieve $90 \%$ control of those accessions.

In summary, kochia inbreds tested in this research showed reduced susceptibility to dicamba $(\mathrm{R} / \mathrm{S}$ ratios of 1.3 to 6.8 ) and fluroxypyr (R/S ratios of 1.4 to 5.7). Weed populations with $\mathrm{R} / \mathrm{S}$ ratios $<4.0$ may not be classified as resistant to an auxinic herbicide, as per the current criteria used for the herbicide resistance surveys (Heap 2014). Among the three inbred kochia accessions tested in our study, Chot-01 inbred met the criteria $(\mathrm{R} / \mathrm{S}$ ratios from 4.0 to 6.8 ), and could be considered resistant to both dicamba and fluroxypyr. The differences in susceptibility of the kochia inbreds (derived from fieldcollected accessions) might be attributed to the differences in time when the auxinic herbicide resistance was selected or introduced into the kochia populations via seed or pollen, intensity or frequency of dicamba/ fluroxypyr use (herbicide selection pressure), or control of the susceptible individuals in a population with alternative herbicides/weed control methods, as suggested by 
Gressel and Segel (1982) and Beckie and Reboud (2009) in other herbicide-resistant weed species.

Wind-mediated tumble mechanism of seed dispersal coupled with pollen-mediated gene flow would ensure rapid spread of herbicide resistance in kochia, especially when the inheritance of resistance to the auxinic herbicide (i.e., dicamba) is conferred by a single dominant nuclear allele (Eberlein and Fore 1984; Stallings et al. 1995; Preston et al. 2009). For instance, there was a rapid expansion of ALS-resistant kochia populations across the US Great Plains and western Canada within a few years of its first occurrence (Primiani et al. 1990; Beckie et al. 2011). Nevertheless, development of auxinic herbicide-resistant kochia within and among fields has been unusually slow (Cranston et al. 2001). This may be attributed to several factors, such as (1) dicamba/ fluroxypyr has been used in conjunction with other herbicides, such as sulfonylureas in wheat, (2) occurrence of auxinic herbicide-resistant alleles in natural weed populations may be rare, or (3) mutations which confer resistance are lethal, with possible fitness cost conferred by the auxinic herbicide resistance in kochia (Jasieniuk et al. 1995; Cranston et al. 2001; Mithila et al. 2011; Kumar et al. 2014b). However, the recent increase in cases of auxinic herbicide-resistant kochia (Heap 2014) needs attention.

Although previous researchers have studied various physiological, biochemical, or molecular aspects of kochia resistance to dicamba (Cranston et al. 2001; Dyer et al. 2002; Kern et al. 2005), the exact mechanism is still unknown, and needs further investigation. Evident from this research, the occurrence of kochia accessions with potential cross-resistance to dicamba and fluroxypyr would further limit herbicide options for controlling this weed, especially in wheat-based cropping systems. Generally, fluroxypyr use in wheat is restricted to in-crop applications, whereas dicamba is used for in-crop, chemical fallow, and post-harvest applications; hence, there may potentially be a greater selection pressure for development of dicamba-resistant kochia. Given this scenario, there is a need for caution in using dicamba in dicamba-resistant crops to be commercialized by 2015 / 2016. With adoption of this new technology, growers should pay greater attention to dicamba use stewardship, and utilize multiple effective modes of action herbicides and other best management practices (Norsworthy et al. 2012) to prevent occurrence of auxinic or multiple herbicide-resistant kochia on their farm fields. Growers should make all possible efforts to prevent seed production from the resistant kochia plants.

\section{ACKNOWLEDGEMENTS}

The authors gratefully acknowledge Montana Wheat and Barley Committee for funding this research. We thank extension agents and growers in the Choteau County, Montana, for their assistance with kochia seed collection from the suspected wheat fields.
Anonymous. 2014a. Banvel herbicide label. [Online] Available: http://www.cdms.net/LDat/ld279006.pdf. [2014 Dec. 20].

Anonymous. 2014b. Starane Ultra herbicide label. [Online] Available: http://www.cdms.net/LDat/ld8EO013.pdf. [2014 Dec. 20].

Baker, D. V., Withrow, J. R., Brown, C. S. and Beck, K. G. 2010. Tumbling: use of diffuse knapweed (Centaurea diffusa) to examine an understudied dispersal mechanism. Invasive Plant Sci. Manage. 3: 301-309.

Beckie, H. J. and Reboud, X. 2009. Selecting for weed resistance: herbicide rotation and mixture. Weed Technol. 23: $363-370$.

Beckie, H. J., Blackshaw, R. E., Low, R., Hall, L. M., Sauder, C. A., Martin, S., Brandt, R. N. and Shirriff, S. W. 2013. Glyphosate-and acetolactate synthase inhibitor-resistant kochia (Kochia scoparia) in western Canada. Weed Sci. 61: 310-318.

Beckie, H. J., Warwick, S. I., Sauder, C. A., Lozinski, C. and Shirriff, S. 2011. Occurrence and molecular characterization of acetolactate synthase (ALS) inhibitor-resistant kochia (Kochia scoparia) in western Canada. Weed Technol. 25: 170-175.

Burton, N., Shirriff, S. W. and Beckie, H. J. 2014. Response of glyphosate-resistant kochia (Kochia scoparia L. Schrad.) to alternative herbicides. Can. J. Plant Sci. 94: 1407-1411.

Christoffoleti, P. J., Westra, P. B. and Moore, F. 1997. Growth analysis of sulfonylurea-resistant and -susceptible kochia (Kochia scoparia). Weed Sci. 45: 691-695.

Cranston, H. J., Kern, A. J., Hackett, J. L., Miller, E. K., Maxwell, B. D. and Dyer, W. E. 2001. Dicamba resistance in kochia. Weed Sci. 49: 164-170.

Crespo, R. J., Bernards, M. L., Sbatella, G. M., Kruger, G. R., Lee, D. J. and Wilson, R. G. 2014. Response of Nebraska kochia (Kochia scoparia) accessions to dicamba. Weed Technol. 28: 151-162.

Dyer, W. E., Cranston, H. J. and Kern, A. J. 2001. Physiological characterization of dicamba resistance in kochia. Proc. West. Soc. Weed Sci. 54: 80.

Dyer, W. E., Goss, G. A. and Buck, P. 2002. Gravitropic responses of auxinic herbicide-resistant Kochia scoparia. Proc. Weed Sci. Soc. Am. 171: 49.

Eberlein, C. V. and Fore, Z. A. 1984. Kochia biology. Weeds Today 15: 5-6.

Friesen, L. F., Beckie, H. J., Warwick, S. I. and Van Acker, R. C. 2009. The biology of Canadian weeds. 138. Kochia scoparia (L.) Schrad. Can. J. Plant Sci. 89: 141-167.

Goss, G. A. and Dyer, W. E. 2003. Physiological characterization of auxinic herbicide-resistant biotypes of kochia (Kochia scoparia). Weed Sci. 51: 839-844.

Gressel, J. and Segel, L. A. 1982. Interrelating factors controlling the rate of appearance of resistance: the outlook for the future. Pages 325-347 in H. M. LeBaron and J. Gressel, eds. Herbicide resistance in plants - Biology and biochemistry. J. Wiley, New York, NY.

Hall, L. M., Beckie, H. J., Low, R., Shirriff, S. W., Blackshaw, R. E., Kimmel, N. and Neeser, C. 2014. Survey of glyphosateresistant kochia (Kochia scoparia L. Schrad.) in Alberta. Can. J. Plant Sci. 94: 127-130.

Heap, I. 2014. International survey of herbicide resistant weeds. [Online] Available: http://www.weedscience.org. [2014 Dec. 30].

Howatt, K. A. 1999. Characterization and management of kochia exhibiting variable responses to dicamba. Ph.D. dissertation. Colorado State University, Fort Collins, CO. 161 pp. 
Howatt, K. A. and Ciernia, M. 2014. Kochia samples from North Dakota with variable response to fluroxypyr. Proc. West. Soc. Weed Sci. 67: 79.

Howatt, K. A., Westra, P. and Nissen, S. J. 2006. Ethylene effect on kochia (Kochia scoparia) and emission following dicamba application. Weed Sci. 54: 31-37.

Jasieniuk, M., Morrison, I. N. and Brule-Babel, A. L. 1995. Inheritance of dicamba resistance in wild mustard (Brassica kaber). Weed Sci. 43: 192-195.

Kern, A. J., Chaverra, M. E., Cranston, H. J. and Dyer, W. E. 2005. Dicamba-responsive genes in herbicide-resistant and susceptible biotypes of kochia (Kochia scoparia). Weed Sci. 53: 139-145.

Knezevic, S. Z., Streibig, J. C. and Ritz, C. 2007. Utilizing R software package for dose-response studies: The concept and data analysis. Weed Technol. 21: 840-848.

Kumar, V., Jha, P. and Reichard, N. 2014a. Occurrence and characterization of kochia (Kochia scoparia) populations with resistance to glyphosate in Montana. Weed Technol. 28: 122-130.

Kumar, V., Jha, P. and Varanasi, A. 2014b. Ecological fitness of auxinic herbicide-resistant kochia. Proc. West. Soc. Weed Sci. 67: 80.

Mengistu, L. W. and Messersmith, C. G. 2002. Genetic diversity of kochia. Weed Sci. 50: 498-503.

Miller, E. K., Myers, T. M., Hackett, J. L. and Dyer, W. E. 1997. Dicamba resistance in kochia (Kochia scoparia L. Schrad): preliminary studies. Proc. West. Soc. Weed Sci. 50: 81 .

Mithila, J., Hall, J. C., Johnson, W. G., Kelley, K. B. and Riechers, D. E. 2011. Evolution of resistance to auxinic herbicides: historical perspectives, mechanisms of resistance, and implications for broadleaf weed management in agronomic crops. Weed Sci. 59: 445-457.

Nandula, V. K. and Manthey, F. A. 2002. Response of kochia (Kochia scoparia) inbreds to 2,4-D and dicamba. Weed Technol. 16: 50-54.

Norsworthy, J. K., Ward, S. M., Shaw, D. R., Llewellyn, R. S., Nichols, R. L., Webster, T. M., Bradley, K. W., Frisvold, G., Powles, S. B., Burgos, N. R., Witt, W. W. and Barrett, M. 2012. Reducing the risks of herbicide resistance: best management practices and recommendations. Weed Sci. 60: 31-62.

Preston, C., Belles, D. S., Westra, P. H., Nissen, S. J. and Ward, S. M. 2009. Inheritance of resistance to the auxinic herbicide dicamba in kochia (Kochia scoparia). Weed Sci. 57: 43-47.

Primiani, M. M., Cotterman, J. C. and Saari, L. L. 1990. Resistance of Kochia scoparia to sulfonylurea and imidazolinone herbicides. Weed Technol. 4: 169-172.

Schwinghamer, T. D. and Van Acker, R. C. 2008. Emergence timing and persistence of kochia (Kochia Scoparia). Weed Sci. 56: $37-41$.

Seefeldt, S. S., Jensen, J. E. and Fuerst, E. P. 1995. Loglogistic analysis of herbicide dose-response relationships. Weed Technol. 19: 218-227.

Stallings, G. P., Thill, D. C., Mallory-Smith, C. A. and Shafii, B. 1995. Pollen-mediated gene flow of sulfonylurea-resistant kochia (Kochia scoparia). Weed Sci. 43: 95-102.

Wicks, G. A., Martin, A. R., Haack, A. E. and Mahnken, G. W. 1994. Control of triazine-resistant kochia (Kochia scoparia) in sorghum (Sorghum bicolor). Weed Technol. 8: 748-753. 